\title{
MOLEKUL
}

\section{Ab-Initio Computational Study : The Activation Energy and Steric Effects in Peptide Synthesis of Ac-AA- $\mathrm{NH}_{2}$ and Ac-AP-NH}

\author{
Indah Pratiwi ${ }^{1}$, Bambang Cahyono ${ }^{1}$, Parsaoran Siahaan ${ }^{1 *}$ \\ 'Department of Chemistry, Faculty of Sciences and Mathematics, Diponegoro University, Semarang, Indonesia \\ *Corresponding author email: siahaan.parsaoran@live.undip.ac.id
}

Received November 05, 2020; Accepted April 21, 2021; Available online July 20, 2021

\begin{abstract}
Ab-Initio computational method can be used for simulating reaction mechanisms, such as concerted reaction mechanism on peptide synthesis. The concerted reaction is one of many possible pathways on how peptide can be synthesized. The purpose of this study are probing the concerted reaction mechanism and comparing the steric effect to the reaction, given by different side-chain of alanine $(\mathrm{A})$ and proline $(\mathrm{P})$. Two dipeptides formed from alanine and proline were computed at $\mathrm{HF}$ $\mathrm{SCF} / 6-31 \mathrm{G}^{* *}$ theory level: $\mathrm{Ac}-\mathrm{AA}-\mathrm{NH}_{2}$ and $\mathrm{Ac}-\mathrm{AP}-\mathrm{NH}_{2}$. The res. Its show the activation energy of $\mathrm{Ac}-\mathrm{AA}-\mathrm{NH} \mathrm{H}_{2}$ and $\mathrm{Ac}-\mathrm{AP}-\mathrm{NH} \mathrm{H}_{2}$ forming via concerted pathway are $167.541 \mathrm{~kJ} / \mathrm{mol}$ and $161.044 \mathrm{~kJ} / \mathrm{mol}$, respectively. The steric difference in side-chain affects the dihedral angle of the structure, and also gives difference to the entropy value of reaction.
\end{abstract}

Keywords: ab-initio; activation energy; peptides; reaction mechanism

\section{INTRODUCTION}

Condensation of amino acids is a crucial reaction in protein chemistry as it represents a key reaction for all life processes. An essential structural element of all proteins is a peptide bond $(\mathrm{C}-\mathrm{N})$, which is formed because of the conjugation between the $\alpha$-amino group of one amino acid and the $\alpha$-carboxylic group of another amino acid (Santos et al., 2014). The detailed knowledge of the peptide bond formation mechanism is vital for understanding of various biological processes, and it is a subject of intensive investigations as such.

Non-catalyzed reaction of peptide bond formation has been studied by Bhunia et al. (2016) and Monajemi et al. (2012). Concerted reaction mechanism is one of possible mechanism propose. It also has been studied using molecular dynamics approach by Trobro and Aqvist (2005) and further by Wallin and Aqvist (2010), as a process of peptides synthesis occurring at cell level. Ribosome transforms genetic information, expressing genes into proteins (Ramkumar \& Ramakrishnan, 2010; Yonath, 2010). Briefly, a peptide formation reaction is a reaction between two active groups: the amine $\left(-\mathrm{NH}_{2}\right)$ group and the carboxylic group $(-\mathrm{COOH})$ from two different amino acids. The reaction mechanism involves the nucleophilic attack of the nitrogen atom from amine group to the carbon of the carboxylic group. Furthermore, a hydrogen atom of the amine group will be attracted to the oxygen atom (hydroxyl group of carboxylic), out in the molecular form of $\mathrm{H}_{2} \mathrm{O}$ and the dipeptide will be produced (Anslyn \& Dougherty, 2006a; Konwar et al., 2016; Solomons et al., 2014). The peptide bond forming reaction according to concerted mechanism shown in Figure 1.

The kind of mechanism in term of the topology of the potential energy surface, the nature of the transition states, the presence or absence of intermediates. Reactants progress over transition states on to intermediates, perhaps through multiple intermediates and ending at products. This type of scenario analysis has a long successful story for studying organic reactions (Dai et al., 2018; Gale et al., 2020; Singh et al., 2020; Trinchillo et al., 2016).

Besides of only studying the pathway from thermodynamics and kinetics, the steric effect also studied as well in some previous studies. It can be seen from the bulky steric structure, bond torsions, or the size of atom attached to the particular chain of organic compound (Elias et al., 2020; Ghosh et al., 2007; Mukheriee et al., 2019). Steric effect relates on how electron are occupied in space and reaction mechanism itself tells how electron go through particular reaction pathway which we desired. However, steric can affect the electron, and finally, can affect on how reaction occurs. 


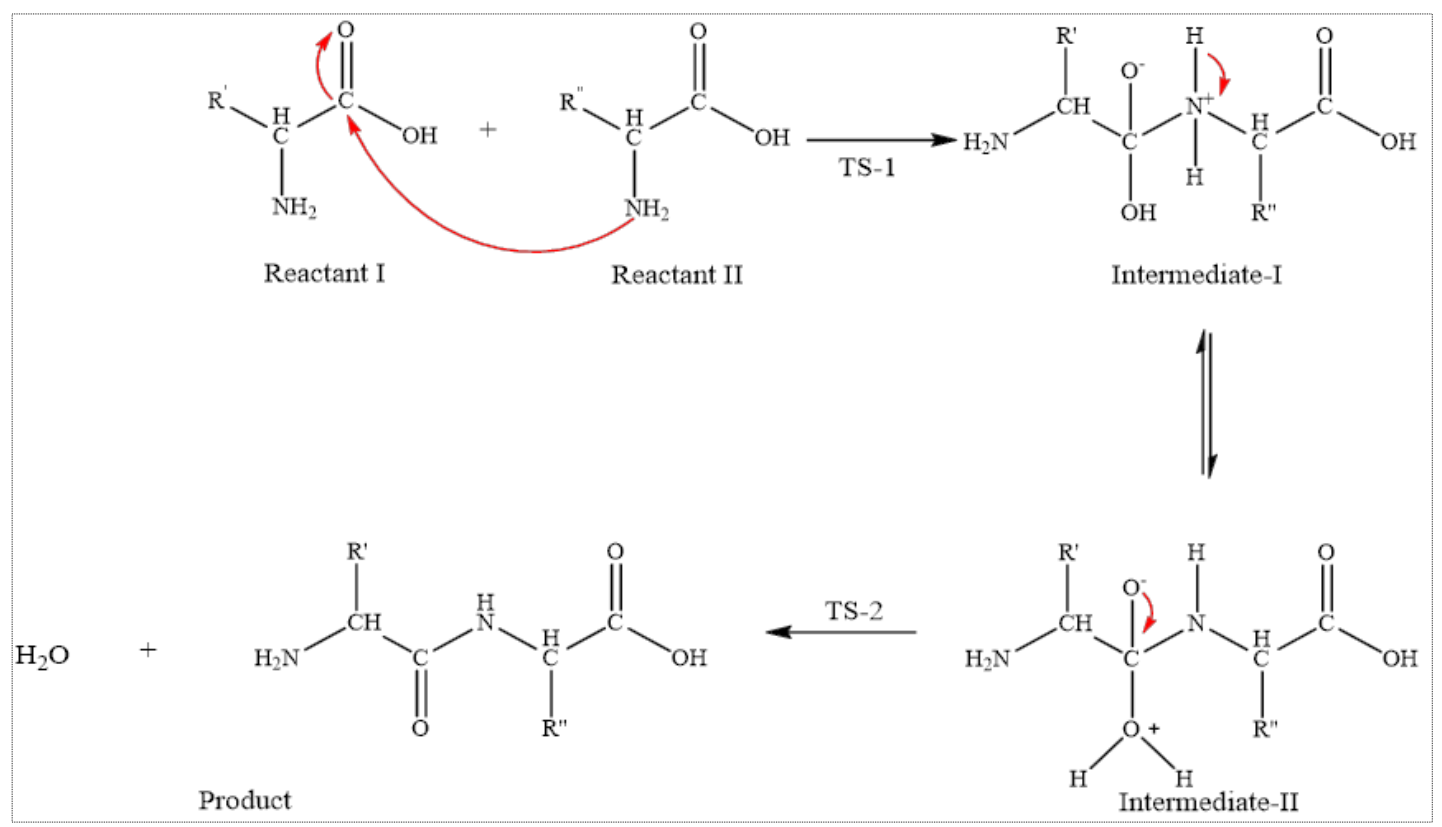

Figure 1. Concerted reaction pathway

In our previous studies, it has compared the steric effect on some dipeptides products of two amino acids with simple side structures, valine (isopropyl side chains) and glycine (hydrogen atom side chains) by Maftukhah (2019) and between alanine amino acids (methyl side chains) and glycine (hydrogen atom side chains) by Dzikrullah et al. (2019). It has been studied the steric effect by concerning some parameters i.e. charge distribution on each atoms, bond lengths, bond angles, torsions (Dzikrullah et al., 2019; Maftukhah, 2019; Siahaan et al., 2017; Siahaan et al., 2019). It also showed there were significant changes in dihedral.

This study will probe the mechanisms of dipeptides formation reactions through concerted reaction pathways between the amino acids alanine and proline. Both amino acids were chosen because in previous studies have been modeled against simpler amino acids namely glycine and valine. In addition, proline has a side chain in the form of a pyrrolidine ring that connects with its amine group. The structure tends to be rigid and less flexible, this may be interesting to study and observe the effect on the geometric changes of its dipeptides products (Das \& Mandal, 2014; El Guerdaoui et al., 2014; Ramaniah et al., 2011; Santos et al., 2014).

The aim of this study is modelling the reaction mechanism of peptide formation on two kinds of dipeptide from alanine (A) series: $A c-A A-N_{2}$ and AcAP- $\mathrm{NH}_{2}$ concerted pathway, As well as comparing how different $\mathrm{R}$-groups tends to influence reaction and structural parameters on products formed. This study conducted using ab-initio computational method, employing HF/SCF theory level and 6-31G** basis set as the suitable basis set used for $\mathrm{C}, \mathrm{H}, \mathrm{O}$, and $\mathrm{N}$ atoms (Cramer, 2013).

\section{EXPERIMENTAL SECTION}

In this study, we started the calculation by proposing reasonable structures for each species involved : reactants, intermediates, transition states, and products (as may be seen in Figure 1). Basis set 6-31 G** was used according the character of the atoms. This kind of small basis set can be employed in order to give sufficient insight into the energy of the molecules. Going along with the low theory level used, the calculation time can also be shorter (Valiev et al., 2010). We also computed the vibrational frequencies analysis at the same level of theory to verify whether each structure is in a stable or transition state (James. et al., 2013).

All calculations were performed using NWChem 6.8 program package, modelled in gas phase. The calculation was done with "task scf optimize" to optimize the molecular structure and "task scf freq" to analyze the vibrational motion. Furthermore, "task scf saddle" was used to search the transition state molecules. (Dykstra et al., 2011; Freza, 2019) .

\section{RESULTS AND DISCUSSION}

As stated in the introduction, two different kinds of products produced through concerted reaction mechanisms: Ac-AA- $\mathrm{NH}_{2}$ mechanism pathway (denoted as mechanism I) and Ac-AP-NH $\mathrm{N}_{2}$ mechanism pathway (denoted as mechanism II). In each case, the energy values, the geometry, and parameters of the stationary points are successively discussed. 
The amino acids structures were calculated to obtain stable molecule structures and minimum energy. The optimized structure of results of alanine (A) and proline (P) can be seen in Figure 2 below. Symbols $r$ and $\alpha$ are used for bond length and bond angle parameters. Optimization of alanine and proline molecules produces molecular energy of $-8,448,105 \mathrm{~kJ} / \mathrm{mol}$ and $10,473,105 \mathrm{~kJ} / \mathrm{mol}$. Reaction begins with the presence of separated two amino acid molecules as the reactants
(R). Reactants in mechanism I consist of two alanine molecules and mechanism II consist of alanine and proline. Those two molecules are attracted by intermolecular forces and become closer, forming into first transition state molecule $\left(\mathrm{TS}^{1}\right)$. In this stage, the amine group from one alanine $\left(-\mathrm{NH}_{2}\right)$ attacks the carbon atom of the carbonyl group $(-\mathrm{COOH})$ in other alanine, since $-\mathrm{NH}_{2}$ is a good nucleophile. This attack leads to $\mathrm{C} 5-\mathrm{N} 4$ bond forming.

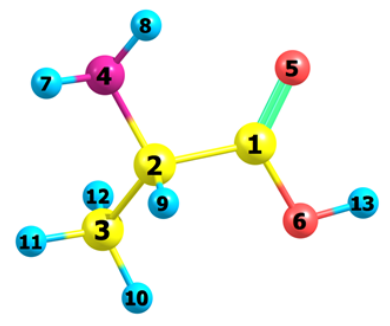

(a)

$\mathrm{r}(\mathrm{N} 4-\mathrm{H} 8) 1,001 \AA \alpha(\mathrm{C} 2-\mathrm{N} 4-\mathrm{H} 8) 110^{\circ}$ $\mathrm{r}(\mathrm{C} 1-\mathrm{O} 5) 1,188 \AA \quad \alpha(\mathrm{C} 2-\mathrm{C} 1-\mathrm{O} 5) 124^{\circ}$ $\mathrm{r}(\mathrm{C} 1-\mathrm{O} 6) 1,327 \AA \quad \alpha(\mathrm{C} 2-\mathrm{C} 1-\mathrm{O} 6) 112^{\circ}$

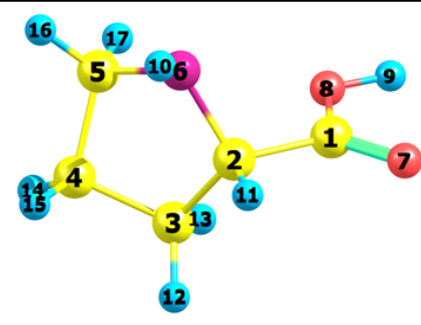

(b)

$\mathrm{r}(\mathrm{N} 6-\mathrm{H} 6) 0,998 \AA \alpha(\mathrm{C} 2-\mathrm{N} 4-\mathrm{H} 10) 110^{\circ}$ $\mathrm{r}(\mathrm{C} 1-\mathrm{O} 7) 1,189 \AA \quad \alpha(\mathrm{C} 2-\mathrm{C} 1-\mathrm{O} 7) 125^{\circ}$ $\mathrm{r}(\mathrm{C} 1-\mathrm{O} 8) 1.329 \AA \quad \alpha(\mathrm{C} 2-\mathrm{C} 1-\mathrm{O} 8) 113^{\circ}$

Figure 2. Optimized structures of alanine (a) and proline (b)

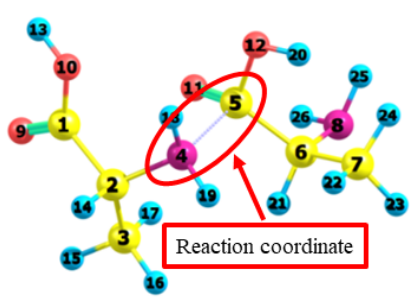

(a)

$\mathrm{r}(\mathrm{N} 4-\mathrm{C} 5) 1,849 \AA, \alpha(\mathrm{C} 5-\mathrm{N} 4-\mathrm{C} 2) 116^{0}$ $\mathrm{r}(\mathrm{C} 5-\mathrm{O} 10) 1,226 \AA, \alpha(\mathrm{O} 10-\mathrm{C} 5-\mathrm{C} 6) 117^{0}$ $\mathrm{r}(\mathrm{C} 5-\mathrm{O} 11) 1,383 \AA, \alpha(\mathrm{O} 11-\mathrm{C} 5-\mathrm{C} 6) 112^{0}$ $\mathrm{v}=-270 \mathrm{~cm}^{-1}$

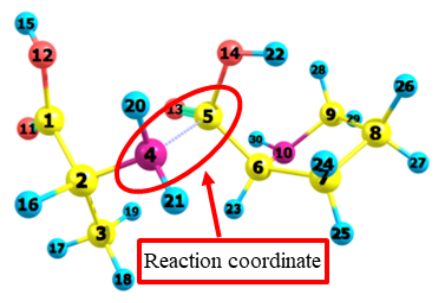

(b)

$\mathrm{r}(\mathrm{N} 4-\mathrm{C} 5) 1,839 \AA, \alpha(\mathrm{C} 5-\mathrm{N} 4-\mathrm{C} 2) 114^{0}$ $\mathrm{r}(\mathrm{C} 5-\mathrm{O} 10) 1,224 \AA, \alpha(\mathrm{O} 10-\mathrm{C} 5-\mathrm{C} 6) 118^{0}$ $\mathrm{r}(\mathrm{C} 5-\mathrm{O} 11) 1,380 \AA, \alpha(\mathrm{O} 11-\mathrm{C} 5-\mathrm{C} 6) 115^{0}$ $\mathrm{v}=-259 \mathrm{~cm}^{-1}$

Figure 3. First transition state (TS ${ }^{1}$ ) structures for mechanism I (a) and mechanism II (b)

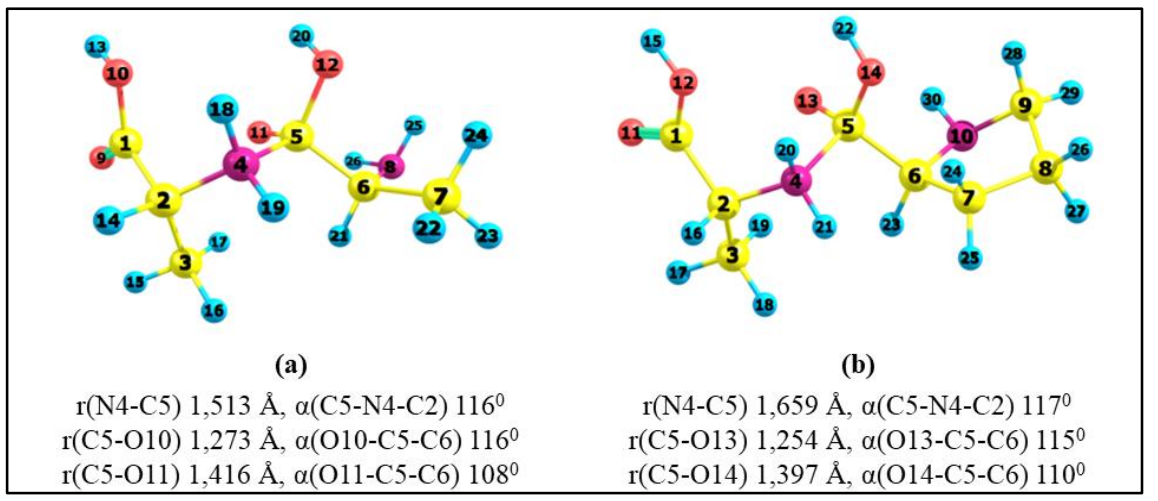

Figure 4. First intermediate (I') structures for mechanism I (a) and mechanism II (b) 
The structures of $\mathrm{TS}^{1}$ and $\mathrm{I}^{1}$ for each mechanism are shown above, on Figure 3 and Figure $4 . \mathrm{TS}^{1}$ has a negative frequency along its reaction coordinate, while I' only has positive frequencies. It implies there is no electron transferring from N4 to C5 anymore because the N4-C5 bond is already formed. Negative frequency implies the structure is in the saddle point (Bachrach, 2014). The negative frequency vibration mode refers to the part where the bond is formed. C5-N4 bond keep shortening, increase its peptide bond character during the reaction. $\mathrm{H} 18-\mathrm{O} 12$ length in mechanism I and $\mathrm{H} 20$ 014 in mechanism II also get closer. Therefore, the proton $\left(\mathrm{H}^{+}\right)$is transferred to the $\mathrm{O}$ atom. As a result, $\mathrm{H}_{2} \mathrm{O}$ molecule is formed inside the second intermediate $\left(\mathrm{I}^{2}\right)$ structure. Furthermore, $\mathrm{H}_{2} \mathrm{O}$ also act as the side product released together with the main dipeptide product of the mechanisms. The releasing $\mathrm{H}_{2} \mathrm{O}$ process illustrated as the second transition state $\left(\mathrm{TS}^{2}\right)$ as elimination of $\mathrm{H}_{2} \mathrm{O}$. This occurs by breaking of O-C bond from $\mathrm{I}^{2}$ structure.

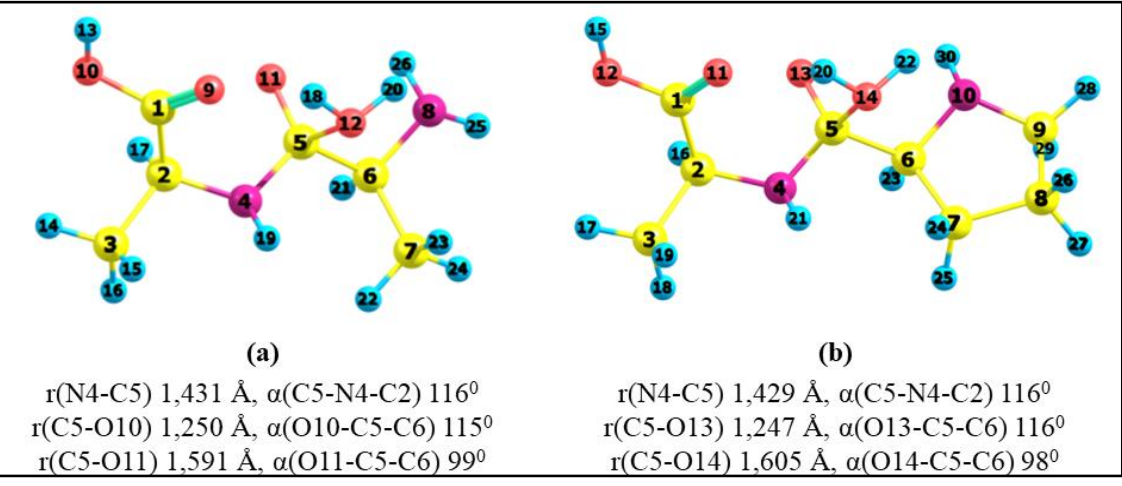

Figure 5. Second intermediate $\left(\mathrm{I}^{2}\right)$ structures for mechanism I (a) and mechanism II (b)

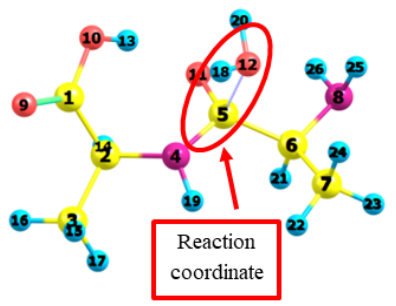

(a)

$\mathrm{r}(\mathrm{N} 4-\mathrm{C} 5)$ 1,404 $\AA, \alpha(\mathrm{C} 5-\mathrm{N} 4-\mathrm{C} 2) 121^{0}$ $\mathrm{r}(\mathrm{C} 5-\mathrm{O} 10) 1,254 \AA, \alpha(\mathrm{O} 10-\mathrm{C} 5-\mathrm{C} 6) 118^{0}$ $\mathrm{r}(\mathrm{C} 5-\mathrm{O} 11) 1,733 \AA, \alpha(\mathrm{O} 11-\mathrm{C} 5-\mathrm{C} 6) 98^{0}$ $\mathrm{v}=-138 \mathrm{~cm}^{-1}$

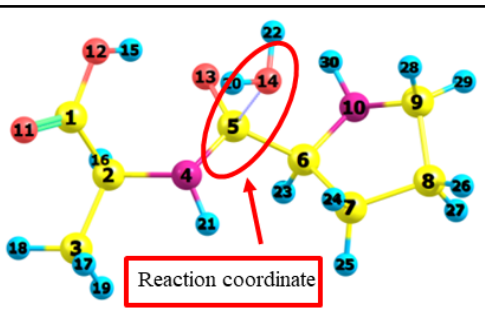

(b)

$\mathrm{r}(\mathrm{N} 4-\mathrm{C} 5) 1,406 \AA, \alpha(\mathrm{C} 5-\mathrm{N} 4-\mathrm{C} 2) 120^{\circ}$ $\mathrm{r}(\mathrm{C} 5-\mathrm{O} 13) 1,250 \AA, \alpha(\mathrm{O} 13-\mathrm{C} 5-\mathrm{C} 6) 117^{0}$ $\mathrm{r}(\mathrm{C} 5-\mathrm{O} 14) 1,753 \AA ⿻, \alpha(\mathrm{O} 14-\mathrm{C} 5-\mathrm{C} 6) 100^{\circ}$ $\mathrm{v}=-96 \mathrm{~cm}^{-1}$

Figure 6. Second transition state (TS 2 ) structures for mechanism I (a) and mechanism II (b)

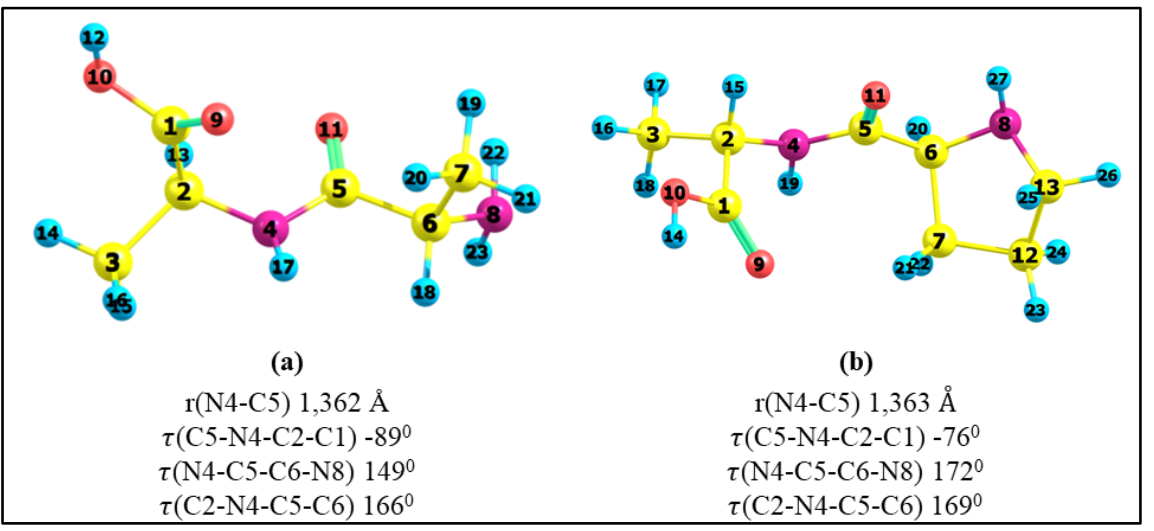

Figure 7. Structure of $\mathrm{Ac}-\mathrm{AA}-\mathrm{NH}_{2}$ (a) from mechanism I and Ac-AP-NH (b) from mechanism II 
The main dipeptide products Ac-AA- $\mathrm{NH}_{2}$ and Ac-AP$\mathrm{NH}_{2}$ are shown in Figure 7. The molecular energy formation of Ac-AA- $\mathrm{NH}_{2}$ is $-14,901.10^{5} \mathrm{~kJ} / \mathrm{mol}$, while for Ac-AP- $\mathrm{NH}_{2}$ is $-16,919.10^{5} \mathrm{~kJ} / \mathrm{mol}$, lower than Ac$\mathrm{AA}-\mathrm{NH}_{2}$ energy. We plotted the potential energy surface from each reaction as shown below in Figure 8 . $X$ axis resembles to reaction coordinate, $Y$ axis resembles to relative potential energy of each molecule from reactant. Both mechanisms have $\mathrm{TS}^{1}$ as their global maximum coordinate. As the matter of fact, we assumed TS ${ }^{1}$ is the step determining the rate of the overall reaction.

Table 1 shows the potential energy corresponding to the TS ${ }^{1}, I^{1}, I^{2}, T^{2}$, and product for both mechanisms with respect those of reactant. It can be observed in all cases $\mathrm{TS}^{1}$ lies higher than $\mathrm{TS}^{2}$. In mechanism I, the activation energy is slightly higher than mechanism II. We can imply that mechanism I is not favorable compared to mechanism II. This trend has also been studied previously by Keresedzile et al. (2014). In the study, a concerted reaction mechanism with the $\mathrm{H}_{2} \mathrm{O}$ molecular catalyst for dipeptides from alanine series (dipeptide in order Ac-AX-NH2, with $\mathrm{X}$ is another amino acid) showed Ac-AP- $\mathrm{NH}_{2}$ mechanism has lower activation energy compared to Ac-AA- $\mathrm{NH}_{2}$.

Furthermore, the other energy profiles such as enthalpy, entropy, Gibbs free energy, HOMO-LUMO gap energy, and reaction rate constant are shown in Table 2. The activation energy of both mechanisms is around $40 \mathrm{~kJ} / \mathrm{mol}$. The same activation energy range value was predicted by Bhunia et al. (2016) for the same mechanism under non-catalyzed reaction condition.

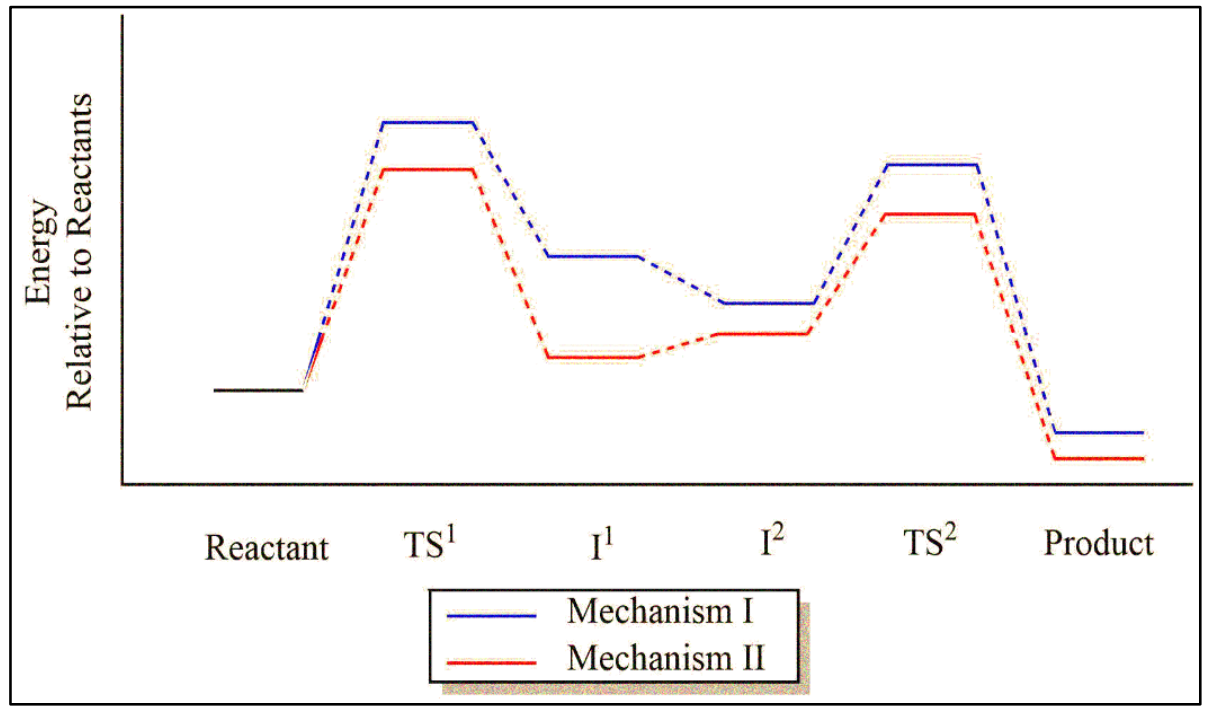

Figure 8. Potential energy surface (PES) plot from mechanism I (blue) and mechanism II (red)

Table 1. Summary of energies $(\mathrm{kJ} / \mathrm{mol})$ at the $\mathrm{HF} / 6-31 \mathrm{G}^{* *}$ level of calculation for concerted mechanism

\begin{tabular}{ccccccc}
\hline Mechanism & Reactant & TS $^{1}$ & $\mathrm{I}^{1}$ & $\mathrm{I}^{2}$ & TS $^{2}$ & Product \\
\hline $\mathrm{I}$ & 0.000 & 167.541 & 166.677 & 159.216 & 161.650 & -16.372 \\
II & 0.000 & 161.044 & 143.046 & 152.800 & 153.128 & -20.263 \\
\hline
\end{tabular}

Table 2. Summary of energies $(\mathrm{kJ} / \mathrm{mol})$ at the $\mathrm{HF} / 6-31 \mathrm{G}^{* *}$ level of calculation for concerted mechanism

\begin{tabular}{ccccccc}
\hline Mechanism & $\begin{array}{c}\text { Ea } \\
(\mathrm{kJ} / \mathrm{mol})\end{array}$ & Ea (kKal/mol) & $\begin{array}{c}\Delta H \\
(\mathrm{~kJ} / \mathrm{mol})\end{array}$ & $\begin{array}{c}\Delta G \\
(\mathrm{~kJ} / \mathrm{mol})\end{array}$ & $\begin{array}{c}\Delta S \\
(\mathrm{~kJ} / \mathrm{mol})\end{array}$ & $\begin{array}{c}\mathrm{E}_{\text {Gap }} \\
(\mathrm{kJ} / \mathrm{mol})\end{array}$ \\
\hline $\mathrm{I}$ & 167.541 & 40.043 & -10.277 & -8.110 & -0.007 & 2.473 \\
$\mathrm{II}$ & 161.044 & 38.490 & -15.219 & -9.636 & -0.022 & 2.487 \\
\hline
\end{tabular}


Table 3. Dihedral Torsion of mechanism I and mechanism II

\begin{tabular}{ccc}
\hline Dihedral $(\tau)$ & \multicolumn{2}{c}{ Degree $\left(^{\circ}\right)$} \\
\cline { 2 - 3 } C5-N4-C2-C1 & Mechanism I & Mechanim II \\
\hline $\mathrm{I}_{1}$ & -62 & -60 \\
$\mathrm{I}_{2}$ & -57 & -58 \\
Product & -86 & -76 \\
$\Delta \tau$ & 34 & 20 \\
\hline
\end{tabular}

Table 3. Dihedral Torsion of mechanism I and mechanism II

\begin{tabular}{ccc}
\hline Dihedral $(\tau)$ & \multicolumn{2}{c}{ Degree $\left(^{\circ}\right)$} \\
\cline { 2 - 3 } N8-C6-C5-N4 & Mechanism I & Mechanim II \\
\hline $\mathrm{I}_{1}$ & 173 & 174 \\
$\mathrm{I}_{2}$ & -167 & -165 \\
Product & 149 & 172 \\
$\Delta \tau$ & 24 & 16 \\
\hline
\end{tabular}

In the other hand, we observed that the entropy changes of mechanism $I$ is slightly higher than mechanism II. The differences between these mechanisms can be attributed to the differences in dipeptide (products) conformations. To see how the conformation changes affect the reaction, we observed some of important dihedrals in the structures which gives significant change during the reaction.

During the reaction, dihedral $(\tau) \mathrm{C} 5-\mathrm{N} 4-\mathrm{C} 2-\mathrm{C} 1$ seems very dynamic and changes significantly. In mechanism I, when I' underwent proton transfer to form $1^{2}$, it was able to experience a freer rotation compared to the two intermediates in mechanism II, seen from the changes of its intermediates on Ac-AA- $\mathrm{NH}_{2}$ mechanism the dihedral can rotate freer than mechanism II's intermediates. Effect of the pyrrolidine ring structure also indicated by the torsion angle changes of N8-C6-C5$\mathrm{N} 4$ during the reaction. Bulky ring structure of proline residue inhibits the single bond free-rotation around the $\mathrm{N}$ terminal of the Ac-AP- $\mathrm{NH}_{2}$ peptides. As a result, the angle of dihedral torsion cannot vary that much.

Single bond rotation is a common phenomenon occur in peptide chain. This intramolecular movement does not occur in every bond in the peptide chain, but only a single bond outside the peptide bonds (Bhagavan \& $\mathrm{Ha}, 2015)$. The $\mathrm{C} 2-\mathrm{Cl}$ is one of those single bonds, its rotation cause changes in peptide chain conformation in the atoms $\mathrm{C} 1-\mathrm{C} 2-\mathrm{N} 4-\mathrm{C} 5$. In the course of the reaction through this concerted pathway, rotation plays a role in increasing hydrogen binding in the structure of the first intermediate so that $\mathrm{H}_{2} \mathrm{O}$ molecules can be formed in second intermediate and released as a side product.

The limitations of free-rotation are seen from the entropy change $(\Delta S)$ on each mechanism. When the ability for free-rotation decreases, the molecular-free path also decreases, resulting in a low entropy $(\mathrm{S})$ value (Peter Atkins, 2010). Ac-AA- $\mathrm{NH}_{2}$ has a considerable entropy change value compared to other mechanisms. Thus, it can be concluded that the Ac-AA-NH mechanism has a larger free path, which is a result of its more dynamic side chain rotation.

Overall, the dipeptide products have a trans conformation geometry structure, pointed out as the dihedral between $2 \mathrm{C} \alpha$, indicated by C2-N4-C5-C6 atoms. These conformations are the most common in dipeptides bonds. With trans geometry, each side chain can have the position as far as possible so that the steric hindrance becomes minimal and provides stable product geometry (Padmanabhan, 2014).

However, this study was only able to provide rough estimates on explaining the differenced in side chains of amino acids can affect the reaction, both in terms of activation energy and other parameters such as enthalpy, entropy, and so on. Further research is needed to provide more exact values using more expensive theory level and basis set, as well as calculating other dipeptide products with the same reaction mechanism employed.

\section{ACKNOWLEDGEMENTS}

Thankful to Faculty of Science and Mathematics, Diponegoro University whch has funded the 2020 research and technology funding scheme.

\section{CONCLUSIONS}

Different side chain of amino acid can affect the peptide bond formation reaction. The activation energies of Ac-AA- $\mathrm{NH}_{2}$ and $\mathrm{Ac}-\mathrm{AP}-\mathrm{NH}_{2}$ via concerted pathway are $167.541 \mathrm{~kJ} / \mathrm{mol}$ and $161.044 \mathrm{~kJ} / \mathrm{mol}$, respectively. Ac-AA- $\mathrm{NH}_{2}$ formation has the highest 
energy. On the structure, the steric difference in side chains affects the dihedral angle of the structure thus giving slight difference to the entropy value of reaction. Intermediates in mechanism I tend to move freer than mechanism II, the entropy of mechanism I higher than mechanism II.

\section{REFERENCES}

Anslyn, E. V., \& Dougherty, D. A. (2006). Modern physical organic chemistry. In Choice Reviews Online,43(06).

CHOICE.43-3398

Anslyn, E. V, \& Dougherty, D. A. (2006b). Modern physical organic chemistry. University science books.

Bachrach, S. M. (2014). Computational organic chemistry. John Wiley \& Sons.

Bhagavan, N. V, \& Ha, C. E. (2015). Chapter 15Protein and Amino Acid Metabolism. Essential of Medical Biochemistry, 2nd Ed.; Academic Press: Amsterdam, The Netherlands, 227-268.

Bhunia, S., Singh, A., \& Ojha, A. K. (2016). Uncatalyzed peptide bond formation between two monomers of glycine, alanine, serine, threonine, and aspartic acid in gas phase: a density functional theory study. The European Physical Journal D, 70(5), 106.

Cramer, C. J. (2013). Essentials of computational chemistry: theories and models. John Wiley \& Sons.

Dai, Y., Hua, Q., Ling, J., Shao, C., Zhong, C., Zhang, X., Hu, Y., Zhang, L., \& Liu, Y. (2018). Quantum chemical calculation of free radical substitution reaction mechanism of camptothecin. Journal of Molecular Graphics and Modelling, 84, 174-181.

Das, G., \& Mandal, S. (2014). Quantum mechanical investigations on the role of $\mathrm{C}$-terminal residue in influencing the structural features of dipeptides containing $\mathrm{N}$-terminal proline. Journal of Molecular Graphics and Modelling, 49, 1-10.

Dykstra, C., Frenking, G., Kim, K., \& Scuseria, G. (2011). Theory and applications of computational chemistry: the first forty years. Elsevier.

Dzikrullah, A., Cahyono, B., Laksitorini, M. D., \& Siahaan, P. (2019). Ab initio computational study of electronic structure part-1: reaction mechanism of peptide bond formation between amino acid alanine and glycine. Journal of Physics: Conference Series, 1217(1), 12053.

El Guerdaoui, A., El Kahoui, Y., Bouriila, M., Tiiar, R., \& El Gridani, A. (2014). Potential Energy Surface (PES) scan of gas-phase L-proline. International Letters of Chemistry, Physics and Astronomy, 19(1), 26-34.

Elias, R. S., Saeed, B. A., Kamounah, F. S., Duus, F., \&
Hansen, P. E. (2020). Strong intramolecular hydrogen bonds and steric effects involving $C=S$ groups: An NMR and computational study. Magnetic Resonance in Chemistry, 58(2), 154162.

Farikhatul Maftukhah, Mekanisme Reaksi Sintesis Peptida Ac-GV-NH ${ }_{2}$ dan Ac-VG-NH $\mathrm{NH}_{2}$ : Studi Komputasi Ab-Initio (Ab-Initio Computational Studies), Departemen Kimia, Universitas Diponegoro. 2019

Freza, S. (2019). Water-assisted peptide bond formation between two double amino acid molecules in the gas phase. Journal of Molecular Modeling, 25(7), 184.

Gale, A. G., Odbadrakh, T. T., Ball, B. T., \& Shields, G. C. (2020). Water-Mediated Peptide Bond Formation in the Gas Phase: A Model Prebiotic Reaction. The Journal of Physical Chemistry A, 124(20), 4150-4159.

Ghosh, S., Mondal, S., Misra, A., \& Dalai, S. (2007). Investigation on the structure of dipeptides: A DFT study. Journal of Molecular Structure: THEOCHEM, 805(1-3), 133-141.

https://doi.org/10.1016/i.theochem.2006.11.004

James., Foresman, J. B., \& Frisch, A. (2013). Exploring Chemistry With Electronic Structure Methods.pdf. In Exploring Chemistry with Electronic Structure Methods (Vol. 2013, Issue 15). https://doi.org/10.1002/adma.200400767

Kereselidze, J., Kvaraia, M., \& Mikuchadze, G. (2014). Quantum-chemical description of influence of the R-groups on formation of peptide bond. Computational Molecular Bioscience, 4(02), 35.

Konwar, M., Ali, A. A., \& Sarma, D. (2016). A Green Protocol for Peptide Bond Formation in WEB. Tetrahedron Letters, 57(21), 2283-2285. https://doi.org/10.1016/i.tetlet.2016.04.041

Monajemi, H., Daud, M. N., Mohd. Zain, S., \& Wan Abdullah, W. A. T. (2012). ONIOM and ab-initio calculations on the mechanism of uncatalyzed peptide bond formation. Biochemistry and Cell Biology, 90(6), 691-700.

Mukheriee, G., Alili, A., Barman, P., Kumar, D., Sastri, C. V, \& de Visser, S. P. (2019). Interplay Between Steric and Electronic Effects: A Joint Spectroscopy and Computational Study of Nonheme Iron (IV)Oxo Complexes. Chemistry-A European Journal, 25(19), 5086-5098.

Padmanabhan, S. (2014). Handbook of pharmacogenomics and stratified medicine. Academic Press.

Peter Atkins, J. D. P. (2010). Physical Chemistry 9th Edition.

Ramaniah, L. M., Chakrabarti, A., Kshirsagar, R. J., Kamal, C., \& Banerjee, A. (2011). Density 
functional study of $\alpha$-amino acids: structural, energetic and vibrational properties. Molecular Physics, 109(6), 875-892.

Ramkumar, S. G., \& Ramakrishnan, S. (2010). Two-Step Folding of Donor- Acceptor Foldamers. Macromolecules, 43(5), 2307-2312.

Santos, A. F. L. O. M., Notario, R., \& Ribeiro da Silva, M. A. V. (2014). Thermodynamic and conformational study of proline stereoisomers. The Journal of Physical Chemistry B, 118(34), 10130-10141.

Siahaan, P, Lalita, M. N. T., Cahyono, B., Laksitorini, M. D., \& Hildayani, S. Z. (2017). Ab initio computational study of reaction mechanism of peptide bond formation on HF/6-31G $(d, p)$ level. IOP Conference Series: Materials Science and Engineering, 172(1), 12040.

Siahaan, Parsaoran, Sipangkar, M. J., Salimah, S. N. M., Aminin, A. L. N., Asyari, M., \& Laksitorini, M. D. (2019). Electronic properties study of reaction mechanism of $\mathrm{CN}$ bonding formation in Ac-DT$\mathrm{NH} 2$ and Ac-TD-NH2 peptide by ab initio computational on $\mathrm{HF} / 6-31 \mathrm{~g}^{* *}$ level. IOP Conference Series: Materials Science and Engineering, 509(1), 12107.

Singh, A., Chayawan, Mehta, S. K., \& Singh, K. (2020). Catalyst free enantioselective amination via SN2 nucleophilic substitution reaction: a computational study. Molecular Simulation, 46(12), 942-946.
Solomons, T. W. G., Fryhle, C. B., \& Snyder, S. A. (2014). Organic chemistry.

Trinchillo, M., Belanzoni, P., Belpassi, L., Biasiolo, L., Busico, V., D'Amora, A., D'Amore, L., Del Zotto, A., Tarantelli, F., \& Tuzi, A. (2016). Extensive experimental and computational study of counterion effect in the reaction mechanism of $\mathrm{NHC}$-gold (I)-catalyzed alkoxylation of alkynes. Organometallics, 35(5), 641-654.

Trobro, S., \& Aqvist, J. (2005). Mechanism of peptide bond synthesis on the ribosome. Proceedings of the National Academy of Sciences, 102(35), 12395-12400. https://doi.org/10.1073/pnas.0504043102

Valiev, M., Bylaska, E. J., Govind, N., Kowalski, K., Straatsma, T. P., Van Dam, H. J. J., Wang, D., Nieplocha, J., Apra, E., \& Windus, T. L. (2010). NWChem: A comprehensive and scalable opensource solution for large scale molecular simulations. Computer Physics Communications, 181(9), 1477-1489.

Wallin, G., \& Åvist, J. (2010). The transition state for peptide bond formation reveals the ribosome as a water trap. Proceedings of the National Academy of Sciences, 107(5), 1888 LP - 1893. https://doi.org/10.1073/pnas.0914192107

Yonath, A. (2010). Hibernating bears, antibiotics, and the evolving ribosome (Nobel Lecture). Angewandte Chemie International Edition, 49(26), 4340-4354. 